\title{
The Arts Therapist in Public: The Dichotomy of Clinical and Performative Improvising
}

\author{
Nicky Haire ${ }^{12}$, Becky White ${ }^{3 *}$, Philippa Derrington ${ }^{4}$ \\ 1 NHS Lothian, UK \\ 2 University of Edinburgh, UK \\ 3 University of the West of England, UK \\ 4 Queen Margaret University, Edinburgh, UK \\ *nickyhaire@gmail.com \\ Received: 28 May 2017 ; Accepted: 29 September 2017 ; Published: 1 November 2017 \\ Editor: Michael Viega Reviewer: Brian Abrams
}

\section{Introduction}

This video is from Concurrent\#2, January 2017 and forms part of an on-going artistic data collection. During this phase of the project a group of music therapists, musicians, dance-movement therapists, and dancers framed their live, improvised encounter with the question: Does the individual's experience and perception of an encounter vary according to one's role?

The video is followed by the artist statements (written and audio recorded) made spontaneously in response to this question, while reflecting on the piece four months after the actual encounter.

\section{Video}

https://player.vimeo.com/video/204859645

Acknowledgements: Emma Bowen Camera \& Edit for ECA/ Concurrent

Dr. Graeme Wilson and Prof. Raymond MacDonald, founders of Concurrent: Improvisation Across Disciplines http://www.concurrent.music.ed.ac.uk/

\section{Context}

Concurrent is a network of key researchers and leading improvisers to share approaches and theoretical insights, apply psychological understandings to collaborative performance and consider how performers share or construct meanings at the cutting edge of contemporary improvisation. Through public events and online dissemination, the network aims to inform and involve a wide range of creative improvisers, academics and audiences interested in transcending disciplines and genres. Concurrent, based at Edinburgh College of Art, University of Edinburgh and funded by the Royal Society of Edinburgh, represents a hub for innovative improvised performance; for new research explaining the unique social and creative process of improvisation; and for the wider application of current thinking on improvisation, for instance in community music or other spheres of social interaction (Wilson, 2016). 


\section{Artist Statements}

\section{Audio}

1. Nicky Haire: music therapist/musician

2. Suzi Cunningham: dance-movement therapist/performance artist

3. Helga Schram: dancer

https://soundcloud.com/voices-mt/sets/the-arts-therapist-in-public-the-dichotomy-ofclinical-and-performative-imrpvovising

\section{Written}

\section{Mairi Campbell (musician: viola and voice)}

When I hear and watch this I'm surprised by how together it sounds and looks! The rich blend of strings created a rich soundscape.

It took a while for me to tune into the dancers and I was struck by how sensitive they were ...

subtle moves and sways that were moving right into the music.

It was interesting to see the instant shift when live voice was introduced ...

I felt a stronger connection to the dancers when and after I'd used voice.

Loved doing this and would like to do more!

\section{Ana Almeida (dancer)}

In the beginning of the performance, I felt I needed some time to tune in my body to the music. The music became my starting point. To do that effectively, I closed my eyes. This consequently implied not establishing eye contact with the musicians or the dancers at this stage. I was just 'listening' to my body.

I then allowed the music to invade my body and take control. I was being moved and that was really nice.

At some point, I felt a presence. Someone was close to me. However, I was not ready to interact. I needed more time before this close encounter. I decided to move away.

There was one moment during which the music became very intense. That made me use very quick bodily accentuations. I very much enjoyed that and kept this experience for a while.

I tended to keep a very strong connection with the music (but without any eye contact with the musicians) and maintain a 'safe' distance from the other dancers. I wonder if this is related with the fact that I am actually a musician who enjoys moving more than a dancer. Music speaks louder to me. I cannot resist it! It definitely takes control of all my moves.

I am on stage but I do not feel I am performing. What I am doing is actually what I am feeling. I am not trying to represent anything for the audience or hold myself. I am just in the moment and I am just doing it. What is happening is so deep and personal (INNER) that is very hard for me to open my eyes and consciously face the audience or interact with someone else on stage (OUTER). However, I feel very connected to the environment that is being created. I am definitely part of it.

Interestingly, I am not ready to allow anyone into my personal space besides the music.

I enjoyed embodying some themes that emerged in the music and recurrently going back to them throughout the performance.

It is interesting to observe how in the middle of the performance the music and the dance were clearly more integrated and cohesive.

Another thing that is very curious is to see the musicians looking at the dancers as if they were scores. However, even though the dancers are clearly responding to the music they do not seem to need to establish eye contact with the musicians. I am wondering what the musicians felt about that... Did they feel corresponded in any way?

One musician mimics the movements of the dancers. That was nice to see. 
I really enjoyed when some common ideas travelled among the dancers, even if a more intimate interaction was not happening between them. It was definitely a very subtle encounter between dancers. Each dancer tended to maintain their personal space separate from the other dancers.

It is interesting to see some dancers attempting to get closer to other dancers at some points, but these moments did not last for a long time. They also tended to keep their positions in space unchanged.

It is clearer that the musicians were more connected with each other than the dancers... possibly because the dancers did not normally dance together.

\section{Discussion}

In January 2016, (Concurrent\#1, Edinburgh, UK) music therapists and dance-movement therapists took Goffman's (1961) sociological concept of encounters as a starting point to generate discussion around non-verbal empathic encounters in their work through a live, improvised performance. The event moved beyond a simple 'role-play' demonstration between therapists, and the felt experience of all participants, including the audience, provided rich discussion around what a therapeutic encounter actually feels like and how enacting it in a public space made it different and similar to any felt encounter in performance/art.

A year later, having now performed 'the encounter' four times with different audiences and participants, we find that this project has grown. It is clearly situated and understood within arts-based research, which spans the worlds of arts and social science (Kara, 2015). In the arts therapies, arts-based research '...is often employed in the pursuit of social justice by offering minority voices an opportunity to make a meaningful contribution to research in a holistic and creative manner' (Ledger \& MacCaffrey, 2015). While 'minority voices' may relate to many of the people we work with as music therapists, the arts therapies in general can also be considered a minority profession. The first two encounters relevantly took place in Scotland - which individually and collectively, is arguably experiencing renewed possibilities for agency, empowerment, and self-determination (Haire \& Bruce, 2016). The Concurrent research network has offered an integrated platform for the arts therapies: finding questions through this artistic experience has led to opportunities for joint thinking and discourse, and further collaboration, with an observable positive impact on the profile and understanding of the arts therapies in Scotland.

In this phase, with the artist statements, the project draws on auto-ethnographic processes (Ellis, Adams, \& Bochner, 2010) encouraging and understanding responses from the participants and audience rooted in their own experiences and social histories. Added to this, the on-going project and this encounter is conceived of and performed entirely by female professionals. This was not intentional and we did not set out explicitly to explore this aspect of an encounter, but this fact cannot be ignored and provides deeper layers of reflection and understanding of the politics of encounters and the importance of context, gendering and status when thinking about roles in performance and therapy.

This project is firmly positioned within the new region of 'improvisation studies', which seeks to explore improvisational processes in arts and related disciplines. The development of this fresh area of study in the 21st century has opened up new ways for music psychologists, visual artists, musicians, dancers, actors, arts therapists, and social scientists to utilize new creative arts research methods (Caines \& Heble, 2015; Kara, 2015; Lewis \& Piekut, 2016). Recent relevant studies which have also used improvisation combined with video and artists statements include: Pras and Cance (2014) who examined special moments in music, asking performers to improvise, watch video and make comments; and Wilson and MacDonald (2015) who investigated improvisational cognitive processes using video of live performance followed by participant interviews. 
Music therapy is an integral part of the encounter presented here. Nicky Haire is one of the musicians and authors; she is a performer and a music therapist. Both roles are heavily ensconced in improvisational practices. The other two authors hold music therapy, teaching, performing and research roles. The collage of roles of improvising performer and therapist has seldom been considered (Brown \& Pavlicevic, 1996). There is some research on musical identities that explores culture and music, musical tribes and musicians identities but little to explore the identity of arts therapists (Finnegan, 1997; MacDonald, Hargreaves, \& Miell, 2002, 2017; MacDonald \& Wilson 2005).

How do we experience our identities and roles as arts therapists, as performers; what are the differences and similarities? Can improvised performance illuminate these issues? And what impact could this have on professional identities in the arts therapies specifically? As we see and hear from the artist statements, entering into an improvised encounter 'as a therapist' or 'as a performer' has a strong impact on how each performer experienced their role, the boundaries of interaction, the embodiment 'on stage', and aesthetic considerations.

Indeed the artist statements do not focus solely on one way of experiencing 'the piece' and we encourage you to approach it as such. As Jerry Garcia (of The Grateful Dead) makes clear when interviewed by Derek Bailey about the role of audiences: “...They share the responsibility for the music..." (Garcia cited in Bailey, 1992, p. 46) and in this case we invite you to share responsibility for the enquiry too.

\section{Responses}

The authors welcome your comments via Vimeo: https://vimeo.com/204859645

Please feel free to respond as you are moved keeping in mind our original question: Does the individual's experience and perception of an encounter vary according to one's role?

How does this encounter make you feel? Do you find links between this and your own professional or personal experiences of negotiating identities and roles in your workplace/everyday?

\section{References}

Bailey, D. (1992). Improvisation: Its nature and practice in Music. Boston, MA: Da Capo Press.

Brown, S., \& Pavlicevic, M. (1996). Clinical improvisation in creative music therapy: Musical aesthetic and the interpersonal dimension. The Arts in Psychotherapy, 23(5), 397-405, https://doi.org/10.1016/S0197-4556(96)00033-0.

Caines, R., \& Heble, A. (Eds.). (2015). The improvisation studies reader: Spontaneous acts. Oxon: Routledge.

Ellis, C., Adams, T., \& Bochner, A. (2010). Autoethnography: An Overview. Qualitative Sozialforschung / Forum: Qualitative Social Research, 12(1), http://dx.doi.org/10.17169/ fqs-12.1.1589.

Finnegan, R. (1997). The hidden musicians: Music-making in an English town (2nd ed.). Middletown, CT: Wesleyan University Press.

Goffman, E. (1961). Encounters: Two studies in the sociology of interaction. Mansfield Centre, CT: Martino Publishing.

Kara, H. (2015). Creative research methods in the social sciences: A practical guide. Bristol: Policy Press.

Haire, N., \& Bruce, K. (2016, April). Taking our place: The impact of the 2014 independence referendum in Scotland on personal, political and professional identities in music therapy. Paper presentation for Re-visioning our voice: Resourcing music therapy for contemporary needs, $2^{\text {nd }}$ British Association of Music Therapy Conference, University of Strathclyde, Glasgow.

Ledger, A., \& McCaffrey, T. (2015). Performative, arts-based, or arts-informed? Reflections on the development of arts-based research in music therapy. Journal of Music Therapy, 52, 441-456, https://doi.org/10.1093/jmt/thv013. 
MacDonald, R., Hargreaves, D., \& Miell, D. (Eds.). (2002). Musical identities. Oxon: Oxford University Press.

MacDonald, R., Hargreaves, D., \& Miell, D. (Eds.). (2017). Handbook of musical identities. Oxon: Oxford University Press. https://doi.org/10.1093/acprof:oso/9780199679485.001.0001.

MacDonald, R., \& Wilson, G. (2005). Musical identities of professional jazz musicians: A focus group investigation. Psychology of Music, 33(4), 395-417, https://doi.org/10.1177/ 0305735605056151.

Meadows, A., \& Wimpenny, K. (2017). Core themes in music therapy clinical improvisation: An arts-informed qualitative research synthesis. Journal of Music Therapy, 54, 161-195, Retrieved from, https://academic.oup.com/jmt/article-abstract/54/2/161/4049211/CoreThemes-in-Music-Therapy-Clinical?redirectedFrom = fulltext.

Lewis, G. E., \& Piekut, B. (Eds.). (2016). The Oxford handbook of critical improvisation studies, Volume 1. New York, NY: Oxford University Press.

Lewis, G. E., \& Piekut, B. (Eds.). (2016). The Oxford handbook of critical improvisation Studies, Volume 2. New York: Oxford University Press.

Pras, A., \& Cance, C. (2014, September). Delving into special moments of free improvisation. Paper presentation for Perspectives on Musical Improvisation II, AHRC-funded Centre for Musical Performance as Creative Practice. Oxford University, Oxford.

Wilson, G. (2016). Concurrent / Exploring improvisations between performing arts practitioners. Retrieved from, http://www.concurrent.music.ed.ac.uk.

Wilson, G. B., \& MacDonald, R. A. R. (2012). The sign of silence: Negotiating musical identities in an improvising ensemble. Psychology of Music, 40(5), 558-573, https://doi.org/ $10.1177 / 0305735612449506$.

Wilson, G. B., \& MacDonald, R. A. R. (2015). Musical choices during group free improvisation: A qualitative psychological investigation. Psychology of Music, 44(5), 1029-1043, https://doi.org/10.1177/0305735615606527. 